\title{
Women Participation in Politics and National Development
}

\author{
Fiemotongha Christopher \\ Department of Political Science, Isaac Jasper Boro College of Education Sagbama, Bayelsa State \\ Nein Godknows \\ Department of Political Science, Isaac Jasper Boro College of Education Sagbama, Bayelsa State
}

\begin{abstract}
The contribution of women to the socio-economic and political development of any modern democratic state is essential and indispensable. This paper examines the extent of women participation in politics and national development in Nigeria. The study adopted secondary data as sources of information. The constraints of women participation in politics pose as hindrances to national development in Nigeria. It is discernible from this study that cultural, environmental and educational factors are major barriers to active women participation in politics. It is part of the objectives of this work to realize active women participation in National political life for a sustainable National development. Government at all levels should embark on enlightenment campaign to sensitize the public on the need for more women to embrace and pursue education as this is a catalyst for active women participation in politics. It is also recommended that coercive legislations should be made at all levels against every form of discrimination against women.
\end{abstract}

Keywords: participation, politics, National development.

DOI: $10.7176 / \mathrm{IKM} / 9-7-03$

Publication date: August $31^{\text {st }} 2019$

\section{Introduction}

Women are homemakers and centre of the family, they are also custodian of social, cultural and fundamental values of society and permanent change are often best achieved through them, in fact full community development is not possible without their outstanding cooperation and effective participation (Omoruyi et al 2008).No doubt, the participation and contributions of women to the political and socio-economic development of any democratic state is immeasurable, women have not taken their rightful place in the political and national life of Nigeria. Though, Nigerian women have shown to be homemakers, custodians of family values, they have also exhibited and demonstrated competence in managing public affairs and leadership positions. As Fasugba (2000) rightly noted, many women today are engaged in activities and jobs hitherto regarded as the exclusive of men, since women have become conscious of their rights, they have continued to slug it out with men in all areas of human endeavours. Nigerian women have been faced with numerous constraints, militating against them in the political arena, beaming from the first republic, though the fourth republic has been seen as a new dawn for women participation in politics as it has more women in government both elective and positions of appointments. The United Nations declaration of 30\% affirmation action for women in the Beijing Conference of 1995 was timely for Nigeria; however there are still constraints yet to be surmounted. First, this paper introduced the study, the participation of women in politics and the constraints facing them. It also evaluated some of the contributions of women to politics and national development.

\section{Theoretical Framework}

The theoretical framework adopted in this study is the systems theory. The systems theory is generally traced to the natural sciences, especially biology. The systems theory has been conceptualized differently by different scholars but generally it has to do with connected parts or things which are interdependent but functions as a whole. The general systems theory was propounded by Ludwig Von Bertallanty in 1920 but the theory was introduced in political science in the mid-sixties. While David Easton and Gabriel A. Almond applied this theory in the field of National politics, Mortan Kaplan applied it in the field of international politics (Agarwal, 2000). The central proposition of the systems approach is that all social phenomena, including the political process, are inter-related. Consequently, it is not possible to fully understand any part of society in isolation from the other parts of the same society, which affects its operation (Alapiki, 2004). As Alapiki has explicitly stated above. Women are a significant part of the political process and society, and for us to fully appreciate and tap from this great potential resource, Nigeria must invest on her women to ensure their greater participation in rural and national politics to aggregate national development.

\section{The Concept of National Development in Nigeria}

The word "National" according to the Oxford Advanced Learners Dictionary is anything connected or shared by a whole nation. It has to do with a phenomenon that relates to a whole nation which could either be an event or a 
subject. The Longman Dictionary of Contemporary English also sees "National" as a phenomenon that embraces a whole nation.

Development on the other hand, in this context, is social and material advancement of a country or people in some chosen areas or in all aspects of a national life. Development has been defused in different ways by different scholars. Development is a continuous process. It has to do with some qualitative changes in the living conditions of the people. According to Allen (2006) any structural change that does not impact the living conditions of the mass of citizens positively in spite of rise in per capita income is questionable and lacking in human content of development. Development is a relative and continuous process to a very large extent, Obikeze et al (2004) sees development as involving the improvement of all facets of human endeavour. The politics, the economy, the culture, and social life of the society must improve before we can comfortably talk of development in such a society. Development is multidimensional, as it has to do with the eradication of poverty, inequality and the reduction of unemployment within the economy.

National development therefore is the collective and overall development of the country. This entails the socio-political, socio-economic and religious advancement of the state though used in this context as socioeconomic development tool. This could be achieved through a collective implementation of policies that are carefully planned by the government to actualize set goals. As Nnamdi (2008) rightly puts it, the concept is used to depict the increase in the location of industries and the provision of infrastructures for massive production and equitable distribution of goods and services to the citizens of a country to enhance their standard of living. National development is encompassing, as it requires not only kind of modern technologies in the developed world and industries but also the moral capacity to sustain it. It requires collective efforts both on the path of citizens and the government. It means improved standard of living, greater awareness and increase in goods and services.

\section{The Concept of Political Participation}

For the purpose of this study, it is necessary to look at the component elements. Anything, whether an institution, society or an association that is related to politics is political. What then constitute politics? Wherever human beings live, they differ in wants, needs and desires and each individual competes with other individuals to satisfy these needs and desires among to the fact that resources are relatively scarce in society. The bid to satisfy these wants and needs usually results in competition and contention, so each group works out for itself on how to resolve these contradictions. The processes by which these basic problems of group life are resolved are what we describe as politics (Ndu, 1998).

There are different dimensions to political participation in every political environment. There are citizens who actively and consciously take part in the activities of government, such as voting, convassing and registering voters, competing for public and party offices, influencing government policies, communicating, with representatives, contributing to election campaigns, etc. there are those group of citizens who, play a passive role in the political system, because participation itself is a voluntary exercise, and there are also another group of citizens that stand indifferent, they are neither here nor there.

Literally political participation entails, voluntarily taking part in politics. Political participation refers to those voluntary activities by which members of a society share in the selection of rulers and directly or indirectly, in the formulation of public policy (Alapiki, 2004).

Political participation is an encompassing social activity, which cuts across political environment systems and societies. Whether the society is a liberal/democratic society or an autocratic, dictatorial system, someone must take political decisions and citizens must participate in the activities of the state either directly or impliedly. Though, the extent of participation varies from one political environment to another and from society to society, there are major factors that determine active political participation. These factors, which often times include; education, illiteracy, cultural orientation, gender difference, the government, etc. determines the extent of political participation in every political system and society. In Nigeria, before now, and even up to this day, gender is a major determining factor of political participation. There are various factors that impedes women participation in politics, as the odds against women participation in politics are more than those against general mass citizens participation. Some of the factors that counts against women politician participation impliedly creates an enabling platform for the monopolistic control of men in the political arena. Participation should be encouraged across board in a democratic state. Democracy demands from the common man a certain level of ability and character, rational conduct and active participation in the government (Apadoral 2004, in Global journal of human social science. Vol xiv version 1 2014). Falade (2014) also captures it thus; 'In a political system, the citizens can be involved in the political process and decision making by joining a political party, voting during election, participating in general campaign, community affairs and other political activities'.

There are also other factors that deter and restrict mass political participation which creates apathy and political lukewarmness amongst citizens. Violence is a major militating factor against political participation in Nigeria. Violence puts fear into many eligible voters who, ordinarily could have come to participate in choosing 
their leaders by voting. Nigerian politics has been characterized with violence right from the First Republic in 1963 to date as there is hardly any election in Nigeria without a record of violent activities reported across the country. Synonymous with Nigeria's political culture is that virtually all elections held so

far in the country from independence are violent-ridding. Political participation of citizens in the political system contributes to the success of the system, but it is otherwise in Nigeria because of the undemocratic nature of our politics, and violent uncertainties that characterize the system, a reasonable number of the citizens see politics as a dirty game which must be eschewed.

Expressing his dissatisfaction on the political apathy displayed by Nigerian citizens in the 2011 general elections, the former INEC Chairman, Professor Attiaru Jega stated thus; 'That there exists voter apathy in Nigeria is no longer contentious. Voters turnout in the just concluded general elections had provided a scientific and empirical evidence of the existence of voter apathy and disinterestedness of sections of the electorate in elections...' this ugly scenario has implications for popular participation and governance

\section{The Contributions of Women to National Development}

Nigerian women have made invaluable contributions to National development from the pre-colonial period era to post independence Nigeria. However, the present era to post is adjudged by scholars and political leaders as an era of rebirth for women participation in national life.

" Women play multiple roles in National Development. In spite of playing the role of home managers, they play a part in running the community as well as meaningfully adding value to National Life. They are homemakers and centre of the family.

No doubt, men play a dominant role in the Nigerian political space, women are closing in on this gap in the fourth republic. Pre-independence Nigeria recorded some notable amazons which includes Queen Amina of Zaria, Moremi of Ile Ife, Emotah of Benin, Efursetan Amwara of Ibadan, among others. Though Nigeria was yet to experience cohesive and sovereign governance, these women made outstanding contributions to regional and national development. However, post-independence Nigeria has made conscious efforts to include women in all aspects of governance, though not with commensurate action. As Nwokocha (2007) observes, however, government realized the decline in moral development as a backlash of the relation of women's roles and tried to redress the situation by seeking modalities to re-integrate women's concern into national development. A clear difference in the post-independence era is the establishment of women's wing in political parties between 1960 and 65. Let us make a brief appraisal of contributions of women in the first republic. Two women made it to the Senate in the first republic (Wuraola Esan and Beatrice Kwango) out of 36 Senate members (Alapiki, 2004). With no woman in the 312 members House of Representatives and Federal Cabinet, the two female senators were said to have been nominated by their parties, as they were not elected. Out of the 250 members that debated the 1979 constitution only 5 were women. Women were said to make up $60 \%$ of the electorate in 1999 but there was not a single woman presidential candidate and no woman contested for governorship in all the 19 states of the federation. In 1983, the 91 member senate had on one woman in the person of Chief (Mrs.) Franca Afegbua, while the aborted third republic had one female senator and 16 House of Representative members, with three women deputy governors out of 30 states of the federation. They were Hajiya Ojikutu of Lagos State, Pamela Sadauku of Kaduna State and Mrs. Cecilia

Ekpeyong of Cross River State (Alapiki, 2004). Unarguably, considering the sequence of women contribution to national life, there seem to be some improvements in an ascending manner from the first republic up to the aborted third republic and present fourth republic.

Contemporary Nigeria has relatively experienced a boost in the efforts of women in national development. As a matter of deliberate government policy, women have been appointed into strategic policy-making positions such as deputy governors, chairmanship of corporate bodies, chief executives of public institution and heads of ministerial departments (Okwuosa 1994, in Omoruyi 2008). Mention must be made of reputable women organizations who are not just being crusaders in women advancement, but pillars of national growth. The National Council of Women Society (NCWS), National Association of Women Journalists (NAWOJ), Women in Nigeria (WIN), and Better Programme for Rural Dwellers (B.L.P.), are some of the feminine organizations that have made frantic efforts towards feasible national development. No doubt, there is a wide margin between men and women participation in national life, the fourth republic is considered a new dawn for Nigeria women as there is a surge in women participation in National Politics with more women appointed as heads of ministries, parastatals, and government institutions and the National Parliament. Notable among these women are - Speaker, House of Representatives, Mrs. Obubumi Etteh, head of Civil Service, Mrs. Ebele Okeke, Petroleum Minister, Mrs. Dozieni Allison Madueke, Mrs. Farida Waziri Economic and Financial Crimes Commission (E.F.C.C.), Mrs. Ngozi Okonjo Iweala - Finance Minister, Minister of Education, Mrs. Oby Ezekwesili, Director General of NAFDAC - Mrs. Dora Akunyili of blessed memory, Mrs. Nenade Usman Minister of Finance, D.G. NAPTIP Ms. Julie Okah-Donli and many more credible and competent women who are still serving in governance. The contribution of women goes beyond agriculture and household activities. As Olurin (1996), Agboola (1996), 
Mabogunge, puts it that, "the narrow perception of women" duties may be attributed to the late arrival of women in the colonial system or administrative works. Though the status of women is changing, however, many believe the decadence in moral standards in the country is a backlash of women exclusion in National Life.

\section{Women Participation in Politics}

The participation of women in politics in Nigeria is replete with restraining and constraining factors which has distanced the Nigerian woman from active politics except for a few. There is a consensus on the need for greater and active participation of women in politics in Nigeria. Right from independence, to date, Nigeria has had both democratically elected governments and military regimes, and in all these governments have conceded to the fact that women have not been treated fairly in the scheme of things.

The Obasanjo administration in its first tenure from 1999-2003 was lack luster on gender equality. The Federal Character Commission over the period appeared to have lost grounds in gender equity, being that the Nigerian population is about $50 \%$ male and $50 \%$ female, government appointments at the centre then did not reflect this balance, but there was a marked improvement over the second tenure, 2003-2007 (Nwokocha, 2007). Though, today if not for the glaring exclusion of women in national politics there was relative improvement in women participation in politics in the previous administration of Goodluck Jonathan, both in elective positions and appointments there is still disequilibrium as the target has not been met. Despite the fact that women are engrossed with domestic activities at the home front, they have contributed immensely to national development right from the pre-independence period to date. Under colonialism, women organized themselves against colonial rule. The Aba Women's Riot of 1929 wherein about 50 women lost their lives

Was a protest against British heavy tax system. Chief Elizabeth Adekagbe, in a bid to record her displeasure against the rise of the Electoral College in the West, led the women movement in the Western region. Women took similar initiative against British indirect rule which gave unprecedented privileges to male traditional rulers, while excluding female traditional power holders from taking part in decision making.

It is pertinent to note, that the struggle for Nigeria's independence cannot be complete without a mention of the contributions of women. Margaret Ekpo made her inputs in the pre-independence constitutional conference that led to Nigeria's independence. Women made immense contributions to national development both in precolonial and post-colonial period, and this has been affirmed by various governments, who have made pronouncements of correcting the imbalance, though more in theory than in practice. The experiences of Nigerian women during the colonial era had compelled government to initiate corrective measures to restore women's dignity in the society (Nwokocha, 2007). From independence Nigerian women began to actively seek self-expression to be rightfully placed. Fifty-eight (58) years after independence, Nigerian women are still begging for equality, despite the various calls for gender equality. Is it that Nigerian women are not competent enough or they are merely relegated to the background by their men counterparts who see them as responsible to the home front?

Nigerian women have proven to be competent in all ramifications; though a women is yet to become the President or Vice President of Nigeria, a woman has become the Speaker of the House of Representatives (Mrs. Patricia Olubumi Etteh), Finance Minister (Mrs. Ngozi Okonjo Iweala and Kemi Adeosun), Petroleum Minister (Mrs. Diezani Allison Madueke), Head of Civil Service (Mrs. Ebele Okeke), First Woman Speaker in Nigeria (Mrs. Magaret Icheen, Speaker Benue State House of Assembly), Deputy Governor (Ipalibo Bambo, Rivers State), Governor, though briefly and later reversed (Dame Virgy Etiaba, Anambra State), to mention but a few, though some of these women have been accused of corrupt practices.

Nigerian women have contributed tremendously to Nation-building and National Development right from the pre-independence era to contemporary Nigeria, their participation in active politics and the opportunities in their disposal in the political arena has not been commensurate.

Though there is a renewed campaign all over the world in democratic and liberal states for gender equity in all aspects of social and political life, not much have being achieved so far especially in third world countries. In Nigeria women involvement in politics is still very much below the international mark. Women are afraid to run for elective position (Omoruyi, 2008). The needs for gender equity have been championed by not just democratic states and governments but also by international organisations. Chapter III article 8 of the United Nations Charter of 1945 included a provision for equality between men and women. Equality for development and peace. There have been concerted and renewed efforts by the United Nations from its first world conference on women in Mexico City in 1975 to her subsequent conferences of Copenhagen (1980) and Nairobi (1985) to the Beijing World Conference on women in 1995. Member states in the Beijing declaration, which was tagged Affirmative action, resolved that $30 \%$ of all positions in government owned institutions and organisations, should be held by women. As Alapiki (2004) explicitly stated, "the 30\% affirmative action provision is designed to be applied at every level of government i.e. federal, state, local government and wards, and within every civil society, village cabinets, political party offices and social organizations". As the call for equity re-echoes, some countries of the world appear to be adamant to this provision of the United Nation's charter. 
In Nigeria, there was rekindled hope in the previous administration of Goodluck Jonathan as active women participation in government surpassed the 30\% affirmative action bench mark of the United Nations that hope has to be kept alive in the present administration. This situation however seems to be fluctuating; women are now making serious and appreciable impact in the political life of the country, especially since the 2005

Beijing conference and women affirmative position (Aweni, 2006). Nigerian women have also made significant contribution to national political life in post-independence era, most especially in the second and fourth republic (1979-1983 and 1999 to date). Nigeria produced the first female senator in the second republic (Mrs. Francis Afeghua) and in the final four years of the fourth republic, three (3) women were elected into the senate and fifteen (15) women into the House of Representatives. The fourth republic was a period of reawakening for Nigerian women. Nigerian women have been proven to be qualified and competent to man any political office, irrespective of the rudiments of such offices. These women have demonstrated commitment to their fatherland in various aspects of National life. Today, Nigerian women, despite their responsibility as home keepers, can compete favourably with their male counterparts in social and political life if given the enabling platform.

\section{Constraints of Women in Politics}

What are the factors constraining women in politics? Nigerian women have made some significant and remarkable socio-political and economic contributions national development in the face of challenging circumstances but they are also confronting women participation in political and national life. First is our value system and popular perception that women belong to the home front, though there is a gradual drift from this perception, most cultures in Nigeria require women to conform to male dominance. This was expressed by Yomi (2007), when he said, "patrieneal system of descent, in which generations are identified through male off spring",

The factors constraining women in politics are numerous. Politics in Nigeria has so many defining factors, most of which determines one's success in the political terrain. As Nwokocha (2007) captures it, certainly, politics involves many things, including meetings, campaigns, and consultations, given rise to factors, natural and artificial, that are log in the wheel of progress for women in politics. Though men are also victims, the odds that count against women participation are more than the challenges men face on the field. The general perception of women's social role is care giver of the home while men are seen as head and chief bread winner of the household; this indirectly restrains women playing active role in politics.

Electoral contests in Nigeria are characterized with violence, mid-night meetings and consultations, nocturnal activities, rumour mongering, character assassination and sometimes destruction of lives and property, and by their nature, these factors scare women from actively participating in politics Elections in Nigeria is a contest of guts, strength and who has more money to throw. Another restraining factor is education and economic strength. Nigerian women most especially in the rural areas do not have the financial strength and wherewithal to confront their men folks in an electoral contest and this is a discouraging factor that inhibits the interest of women in politics.

Nocturnal meetings and consultation which are convenient for most political big wigs reduces women participation in active politics. Most women cannot afford to be part of such midnight forums, especially when religion and tradition frowns at it. Most women in the rural areas lack the required political education to make vital decisions on their own, hence making them vulnerable to political misfits, or subjects them to the dictates of their husbands.

In spite of these impediment restraining women from popular participation in politics, the era of total dominance by men is gradually winding up, as Nigerian women are not only centre of the family and custodians of societal values but have also demonstrated competence and confidence in contributing to the socio-political and economic development of the country.

\section{Conclusion and Recommendations}

This paper painstakingly discussed the participation of women in politics, and the contributions of women to national development in Nigeria. It also examined the many constraints confronting women participation in politics and the need to correct the imbalance and ensure that an enabling environment is created for greater women participation in politics and national development. Far reaching recommendations are made along the following lines;

(a) Governments at all levels should embark on periodic enlightenment campaign on the need and benefits of greater women participation in politics.

(b) Government should make education at the basic and secondary level free and compulsory for the girl child.

(c) Political parties can also encourage women participation by making party nomination forms free for women seeking elective positions.

(d) It is also recommended in this paper that, in order to tap from the women resource and ensure optimal 
women contribution to national development, the Nigerian state should improve on the $30 \%$ affirmative action, even though it is yet to adhere strictly to this benchmark.

(e) It is also the responsibility of the Nigeria state to remove the religious, cultural, institutional and artificial barriers which have relegated and incapacitated the Nigerian women from active national life.

\section{References}

Agarawal, R.L (2000), Political Theory. New Delhi: S. Chand and Company.

Ake, C (2001), Democracy and Development in Africa, Ibadan. Spectrum Books.

Alapiki, H.E (2004), Politics and Governance in Nigeria. Port Harcourt: Amethyst and Colleagues Publishers.

Allen, F. (2006), Development administration. Port Harcourt: Fiombeng publications.

Aweni, B. (2006,) Nigerian women and political participation. Enugu: fourth dimension publishers

Falade, D.A. Global Journal of Human Social Science, vol. XIV, Version 12014.

Fasugba .O. (2000), tough women only. The punch 2/5/2000 page 25.

Ibodje, W.E (2009), Administration of Development. Warri: Eregha Publishers.

Ibodje, W.E (2000), Elements of Public Administration. Warri: Lindospat Limited.

International Journal for Innovation Education and Research. www.ijler.net. Vol.3 No-5, 2015.

Journal of Public Administration and Policy Research, http://www.academic journals.org/jpapaer vol. 3(9), pp.237-241, 2011.

Ndu, E.C (1998), Ancient and Mediaval Political Theory. Owerri: Springfield Publishers.

Nnamdi, B.S (2008), Basic Issues in Logic and Philosophy. Port Harcourt: Divine Technologies.

Nwokocha, B.O (2007), Politics and Administration in Nigeria. Aba: Eagle Publishers.

Omoruyi, E.O (2008), The Dynamics of Community Development. Benin: Gift-Print Associates.

Obikeze, S.O and Obi E.A (2004) Federalism and National integration in Nigeria. Onitsha: bookpoint Ltd.

Yomi, M.K (2007) Women, the disadvantaged species. Ibadan: third world information services publishers 